\title{
Microvinifications in wild grapevine relic populations of Spain and France.
}

\section{Microvinificaciones de poblaciones relictas de vid silvestre de España y Francia.}

\author{
Carlos A. Ocete ${ }^{1}$, Rafael Ocete ${ }^{1}$, María C. Ayala ${ }^{2}$, José María del Río ${ }^{3}$, Miguel Lara ${ }^{4}$, \\ Juanjo Hidalgo ${ }^{*}$, José M. Valle ${ }^{6}$, Álvaro Rodríguez-Miranda 6
}

\begin{abstract} characteristics of these wild wines.

\footnotetext{
1 Freelance, Tirgo (La Rioja) (Spain)

2 Instituto La Laboral, Lardero (La Rioja) (Spain)

3 Bodegas Ramón Bilbao (Haro, La Rioja) (Spain)

4 IFAPA "Rancho de la Merced", Jerez de la Frontera (Cádiz) (Spain)

5 Laudioalde Lanbide Eskola \& Aunia Kultura Elkartea (Álava) (Spain)

6 Universidad del País Vasco (UPV/EHU),

Escuela Universitaria de Ingeniería, Vitoria-Gasteiz, Spain

* Corresponding author: juanjoaunia@gmail.com
}

The microvinification of nine Eurasian wild grapevine populations situated in different habitats in La Rioja (Spain) and the Basque Country (Spain, France) were carried out. Populations were observed at flowering time in order to assess the presence of male and female vines. Both harvests took place during the last week of October and the first week of November in 2015 and 2016. Bunches were destalked by hand selecting only ripe grapes, pressed and the amount of must in each sample was weighed. The mixture of must with seeds and skins were fermented at $20^{\circ} \mathrm{C}$ with native yeasts without the addition of Potassium metabisulphite. The principal objective was to determine the main oenological

Due to the small size of the grapes and the fact that their seeds (1 or 2) are quite bulky, the volume of must obtained is very low in each microvinification (15.3 and $16.7 \%$ in weight). In 2015, they showed higher values of alcoholic concentration, lower total acidity and higher $\mathrm{pH}$ than with the wines of the year 2016 because berries were more mature 
and healthier. On the other hand, the ethanol concentration lies between 6.5 and $9 \%$. In both years, the total acidity values are high due to the elevated content of tartaric acid, situated between 5.3 and $7.2 \mathrm{~g} / \mathrm{l}$. The color intensity of wines presents high values, between 15 and 23. This is closely related to the high content of anthocyanins, between 470 and $531 \mathrm{mg} / \mathrm{l}$ and the high total polyphenols index, within the interval $(65.8,107)$. In all the samples both kinds of values are considered appropriate for young red wines.

These wild wines may suggest that the wild grapevine is a very interesting phytogenetic resource. It might improve the acidity and color intensity of wines by crossing with red cultivars, a very important characteristics in the present context of climatic change, mainly in warming regions, such as the Mediterranean vineyards.

Key words: climatic change, habitats, phytogenetic resource, relic populations, vinification, Vitis vinifera L. subspecie sylvestris (Gmelin) Hegi.

\section{Resumen}

Se ha realizado la microvinificación de nueve poblaciones de vid silvestre euroasiáticas situadas en diferentes hábitats de La Rioja (España) y el País Vasco (España, Francia). Las poblaciones se observaron previamente en el momento de la floración para evaluar la presencia de ejemplares masculinos y femeninos. Ambas vendimias tuvieron lugar durante la última semana de octubre y la primera de noviembre de 2015 y 2016. Los racimos se despalillaron a mano seleccionando solo bayas maduras, se prensaron y se pesó la cantidad de mosto de cada muestra. La mezcla de mosto con semillas y pieles se fermentó a $20^{\circ} \mathrm{C}$ con levaduras nativas sin adición de metabisulfito potásico.

El objetivo principal era conocer las principales características enológicas de estos vinos de vid silvestre. Debido al pequeño tamaño de las bayas y al hecho de que las semillas (1 o 2) son bastante voluminosas, el volumen de mosto obtenido es muy bajo en cada microvinificación (15,3 y 16,7\% en peso). En 2015, mostraron valores más altos de concentración alcohólica, menor acidez total y mayor pH que en los vinos del año 2016, porque las bayas eran más maduras y saludables. Por otro lado, la concentración de etanol se sitúa entre 6,5 y $9 \%$. En ambos años, los valores de acidez total son altos debido al alto contenido de ácido tartárico, situado entre 5,3 y 7,2 g / I. La intensidad del color de los vinos presenta valores altos, entre 15 y 23 . Esto está estrechamente relacionado con el contenido elevado de antocianinas, entre 470 y 531 mg / I y el elevado índice de polifenoles totales, situado dentro del intervalo (65.8-107). En todas las muestras, ambos tipos de valores se consideran apropiados para vinos tintos jóvenes.

Estos vinos pueden sugerir que la vid silvestre es un recurso fitogenético muy interesante. Podrían cruzarse con variedades tintas de cultivo, con el fin de aumentar la acidez y la intensidad del color de los vinos. Estos son parámetros muy importantes en el marco actual de cambio climático, principalmente en regiones cálidas, como los viñedos mediterráneos.

Palabras clave: cambio climático, hábitats, poblaciones relictas, recurso fitogenético, vinificación, Vitis vinifera L. subspecie sylvestris (Gmelin) Hegi. 


\section{Laburpena}

Errioxako (Espainia) eta Euskal Herriko (Espainia, Frantzia) hainbat tokitako bederatzi basamahatsondo eurasiarren mikroardogintza egin da. Populazioak loraldi unea baino lehenago behatu ziren, ale maskulino eta femeninoen presentzia ebaluatzeko.

Bi mahats-bilketa horiek 2015eko eta 2016ko urriko azken astean eta azaroaren lehenengoan egin ziren. Mahats-mordoei txortena kentzea eskuz egin zen, soilik baia helduak aukeratuta, eta ondoren prentsatu egin ziren eta lagin bakoitzeko muztio kopurua pisatu zen. Muztioa, haziekin eta azalekin nahastuta, 20 graduan hartzitu zen berezko legamiekin, metabisulfito potasikorik gehitu gabe. Basa-mahastietako ardo horien ezaugarri enologikoak ezagutzea zen helburu nagusia.

Baien tamaina txikikoak izanik eta haziak (bat edo bi), berriz, nahiko handiak, lortutako muztio-bolumena oso urria izan da mikroardogintza bakoitzean (\%15,3 eta \%16,7 pisuan). 2016koekin alderatuta, 2015ekoek alkohol-kontzentrazio gehiago, garraztasun gutxiago eta $\mathrm{pH}$ handiagoa erakutsi zuten, baiak helduagoak eta osasungarriagoak zirelako. Bestetik, etanol kontzentrazioa \%6,5 eta \%9 artean dago. Bi urte horietan, azido tartariko-eduki handiaren ondorioz, 5,3 eta 7,2 g/l artean, garraztasun osoaren balioak altuak izan dira. Ardoen koloreen intentsitateak balio altuak ditu, 15 eta 23 artekoak. Horrek lotura estua du antozianina-eduki handiarekin (470 eta 531 mg/l artean) eta polifenolen osoko-indize handiarekin (65.8 eta 107 artean). Lagin guztietan, bi balio mota horiek egokitzat jotzen dira, ardo beltz gazteak izanik. Ardo horiek erakutsi dute basamahatsondoa oso baliabide fitogenetiko interesgarria dela. Mahats beltzen barietateekin gurutza litezke, ardoen garraztasuna eta kolore-bizitasuna handitzeko. Parametro horiek oso garrantzitsuak dira klima-aldaketako egungo testuinguruan, batez ere eskualde beroetan, hala nola Mediterraneo aldeko mahastietan.

Gako hitzak: aldaketa klimatikoa, habitat, populazio erreliktoak, baliabide bitogenetikoa, Vitis vinifera L. subspecie sylvestris (Gmelin) Hegi.

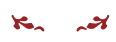

\section{Introduction}

The wild grapevine, Vitis vinifera L. Subsp. sylvestris, constitutes the ancestor of actual cultivars, belonging to Vitis vinifera L. subsp. sativa L. (DC) Hegi, mainly hermaphrodite. This wild subespecies are geographically distributed between the Iberian Peninsula and Afghanistan, where its main habitats are river-bank forests, flood plains, colluvial positions on the slopes of hills and mountains and sandy soils (Arnold, 2002; Susaj et al., 2014). Some populations are also growing in the African Maghreb. The habitats including this Vitaceae in Europe and Africa are situated between the parallels $49^{\circ}$ $28^{\prime}$ (Stadt park of Ludwigshafen, Rhine river) and 31 $21^{\prime}$ (Ourika river, Morocco) (Ocete et al., 2007). 


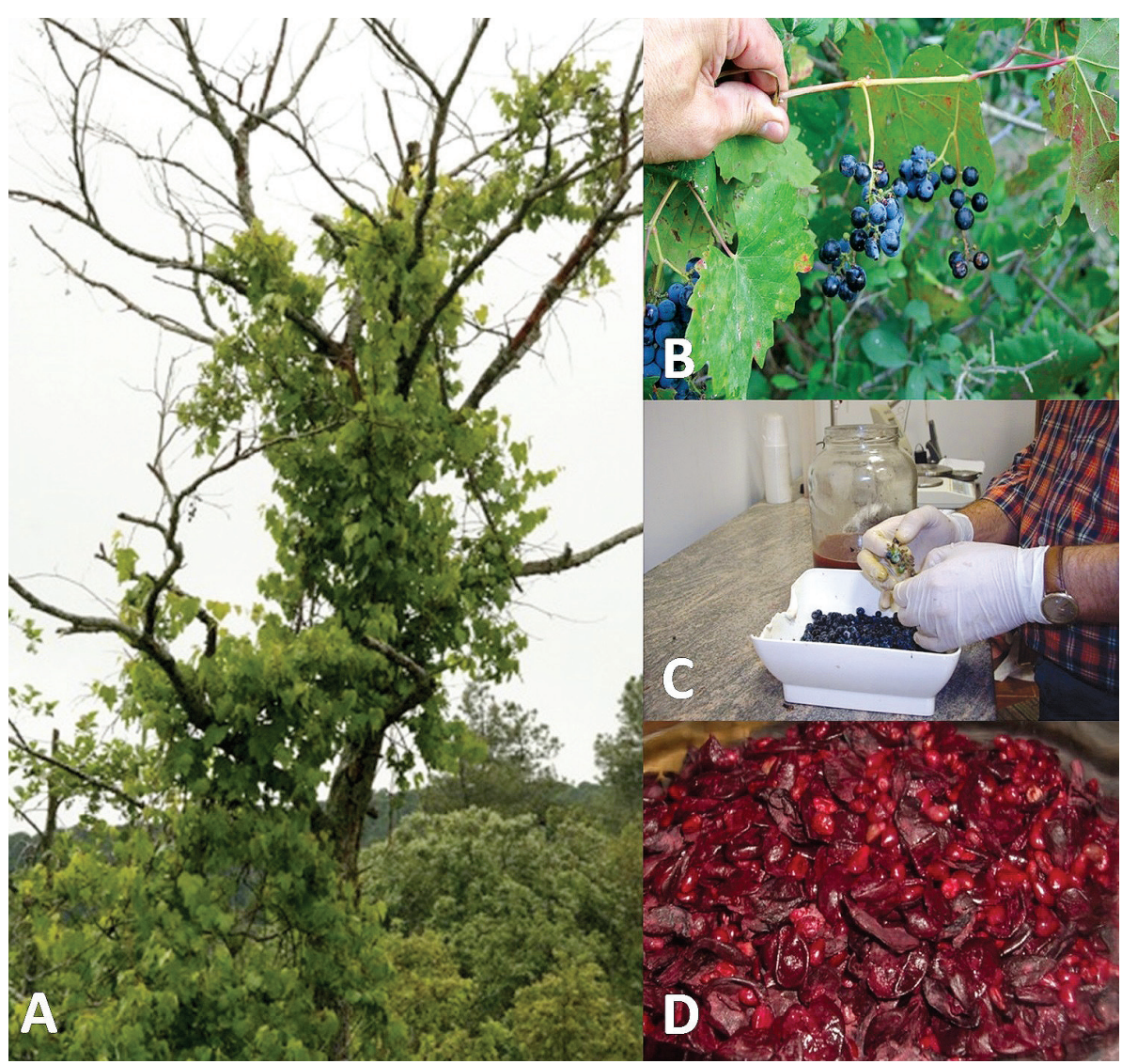

Fig. 1.- A. Wild grapevines climbing on a tree used as supporter (Acotz-Guéthary, France), B. Bunches of wild grapes (Iregua river, La Rioja), C. Manual destalking of the bunches and selection of mature berries, D. Skins and seeds after pressing the berries.

Fig. 1.- A. Vides silvestres trepando a un árbol utilizado como tutor (Acotz-Guéthary, France), B. Racimos de uvas silvestres (río Iregua, La Rioja), C. Despalillado manual de los racimos y selección de bayas maduras, D. Pieles y semillas después de prensar las bayas.

In the cited three-continental area, there is only one species of autochthonous Vitis, a very low diversity of this genus compared with the high number of native species growing in North America and China (Martínez de Toda, 1991). Its populations are conformed by heliophilous and hydrophilic lianae climbing on bushes and trees of the accompanying vegetation (figure $1 \mathrm{~A}$ ). The evolutionary legacy has accumulated in this grapevine physiological, ampelographical and reproductive characters that improve their survival in their habitats. Therefore, it is associated with other ecologically complementary plants (García Novo, 2007). 
The flowers of the male Eurasian wild vines contain five stamens and absence of gynoecium (Type I). There are another male liana with flowers with a small development of gynoecium (Type II) (OIV, 2009; Zito et al., 2016). In both cases, pollen is tricolporated, with holes for the exit of the pollinic tube. On the other hand, female vines have a well-developed gynoecium and reflexed stamens. Their pollen is acolporated, with absence of holes, so fertilization is crossed (Gallardo et al., 2009). At present time, the procedure of domestication started when man discovered hermaphrodite plants due to a mutation on male specimens. They produce a higher harvest than female vines because their pollen is similar to male ones and can have self-pollination (Ocete et al., 2007).

However, seeds from wild female berries are morphologically different from cultivated ones, the study of them in archaeological findings can indicate the consumption of wild or cultivated berries (Terral et al., 2010). Due to this fact, at present, the first proofs of domestication were found in Shulaveri Gora (Georgia, Southern Caucasus) (Chilashvili, 2004; Mc Govern, 2003; 2004).

The domestication of the grapevine is understood as an evolutionary human-made process, where the hermaphroditism, the sugar and acid content of the must, the uniformity of the maturation stage and the constancy of production have been sought, as well as the adaptation to climatic conditions of vineyards (Mariani et al., 2018) and the tolerance to pests and diseases. Over time this process will degenerate into genetic erosion (Ocete et al., 2007). In fact, there were around 8,000 cultivars in all over the world. Approximately 1,500 of them are conserved in actual vineyards, where only some clones belonging to 16 varieties occupy practically a $50 \%$ of the total surface of this culture (Anderson et al., 2017). Moreover, the adoption of vegetative propagation of clones constitutes a double edged sword: although it provided a benefit by ensuring true breeding cultivars, it also discouraged the generation of unique cultivars through crosses (Ben-Nun, 2018).

Legal measures are necessary to prevent the continuous and alarming disappearing of the wild grapevine population, according to conclusions of the European COST Action 1003: Viticulture (Ocete et al., 2015). This subspecies with a heavy genetic diversity and free of human selection could be an interesting threatened phytogenetic resource (Zdunic et al., 2017) to obtain new root-stocks and cultivars facing the possible effects of climate change. The greater part of these populations still conserved are relic, due to the negative effect of an intense variety of anthropic impacts (Terpó, 1969; Arnold, 2002), even inside countries with a specific legal protection for this taxon, as France (Rodríguez et al., 2016). Definitely the overexploitation, accumulation of ecological changes and reduction in natural surfaces and extinctions has led to a crisis of planetary diversity in which the wild vine is immersed (Garcia Novo, 2007). Spain houses the biggest surface of vineyard in all over the world, but there is not any specific law for the conservation of this taxon at national or regional levels. 
In opposite way, in France there is the decree of January 20, 1982, which provides for the protection of wild grapevine (République Française, 1982). In spite of this, several natural habitats containing wild grapevine have been destructed recently around St. Jean de Luz in Acotz-Chibau area (Lapurdi, Pyrénées-Atlantiques) (Rodríguez et al., 2016). To try to conserve that threatened phytogenetic, in the geographical area of this paper two germplasm banks were constituted at the University of La Rioja and in the Estación Hortifrutícola de Zalla, this latter belonging to the Bizkaia province government (Bizkaiko Foru Aldundia). A reserve of wild grapevines was also created around Arreo lake (Communitary Interest Place ES2110007) by the Álava province government (Arabako Foru Aldundia), a place included in the Life Tremedal project.

In some regions of Germany and Italy wild bunches were mixed with the cultivated ones to increase the wine production (Anzani et al., 1993). Wild bunches were also used for the typical Sardinian vino de vulpa produced by shepherds up to about twenty years ago. Curiously the sale of wild bunches was forbidden in some regions, as in the case of Sardinia, due to no generate taxes, as it was shown explicitly in the Carta de Logu, a document included in the Giudici arborea (14th century) (Lovicu, 2008). Vinegar was also produced in a homemade way in Andalusia, mainly in Sierra Morena and Serranía de Grazalema mountain-ranges up to the end of the last century (Ocete et al. 2007). There is rather scarce information available in the literature on the chemical profile of wild vine, although they were the first ones produced and consumed by people.

The aim of the present paper is to show the main oenological characterization on microvinifications carried out in 2015 and 2016 with bunches belonging to nine populations from Northern Spain and South-Western France, taking into account that the Iberian Peninsula could has been a secondary center of domestication for grapevines (Arroyo-García et al., 2006; De Andrés et al., 2012).

\section{Material and methods}

The present study was focused on relic wild grapevine populations situated in the Ebro river basin, more precisely, in La Rioja (Martínez de Toda et al., 2017), some places of the Spanish Basque Country: Álava province, Cantabrian coast and Bidasoa river in Gipuzkoa, which ampelographical description were made by Ocete et al. (2004) and the Labourd (Lapurdi) in the French Basque Country (Département des Pyrénées-Atlantiques) (figure 2).

Coordinates of the different sampling places and the percentages of must extracted from the total weight of mature berries are shown in Table 1. 


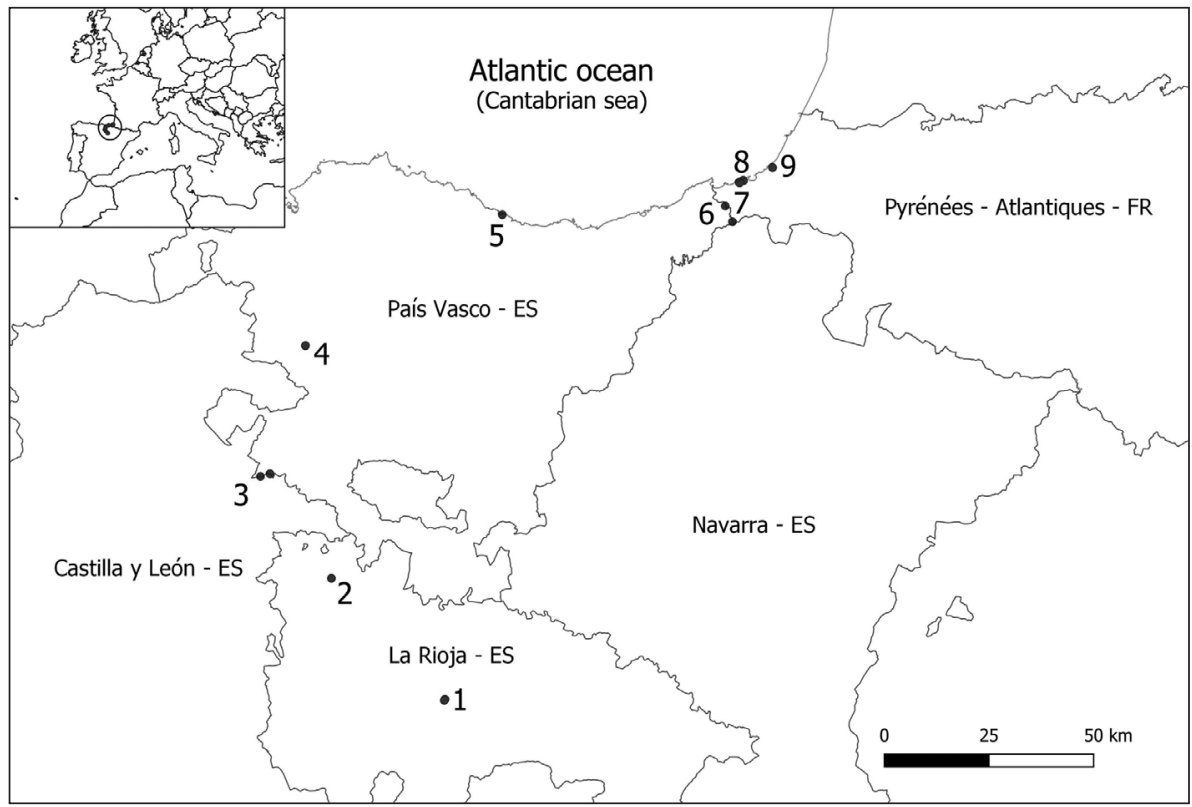

Fig. 2.- Location of the populations used in this work: 1. Iregua River, 2. Agualinos creek, 3. Ebro river (near Sobrón), 4. Amurrio, 5. Saturraran beach, 6. Bidasoa river, 7. Sokoa, 8. Chemin d'Etzan, 9. Acotz-Guéthary.

Fig. 2.- Ubicación de las poblaciones utilizadas en este trabajo. 1. Río Iregua, 2. Arroyo Agualinos, 3. Río Ebro (zona de Sobrón), 4. Amurrio, 5. Playa de Saturraran, 6. Río Bidasoa, 7. Sokoa, 8. Chemin d’Etzan, 9. Acotz-Guéthary.

The types of habitats of the populations that are the object of the present work were:

Alluvial: Iregua river, Agualinos creek, Ebro river, Bidasoa river, Chemin d'Etzan.

Alluvial and colluvial: Sokoa, Acotz-Guéthary.

Colluvial: Amurrio.

Sandy soils: Saturraran beach.

The distribution of wild grapevine populations is very patchy and their size seems to have been reduced and confined to forest edges. These places are linked to a high human impact, and the survival of grapevines in such environments is doubtful (Arnold, 2002).

The confirmation of the presence of the dioecious character of the vines of each population was carried out at flowering time in 2015 (first-second week of June). Male exemplars show flowers type I (OIV, 2009). The harvest of female bunches took place along the last week of October and first one of November in 2015 and 2016. 
All the female vines produced smalland very scattered red bunches; therefore, harvesting becomes a difficult task requiring stairs and telescopic scissors, being the productivity very scarce. Harvests were carried out on 2-6 available specimens of each population. The berry size was always under $1 \mathrm{~cm}$ of diameter in all the samples (figure $1 \mathrm{~B}$ ).

Bunches were destalked by hand selecting only mature berries (figure 1C). The berries of each location were weighted. They were squeezed by a manual press, without breaking the seeds. The must was separated from the skins and seeds of each sample using a vacuum filter (figure 1D). Once each must sample was weighted. Later, the corresponding seeds and skins were added to start the fermentation (Table 1).

\begin{tabular}{|c|c|c|c|c|c|c|c|c|c|}
\hline \multirow{3}{*}{ ID } & \multirow{3}{*}{$\begin{array}{c}\text { Sampling } \\
\text { place }\end{array}$} & \multirow{2}{*}{\multicolumn{2}{|c|}{$\begin{array}{c}\text { Geographic } \\
\text { coordinates } \\
\text { and heights } \\
\text { above sea level }\end{array}$}} & \multicolumn{3}{|c|}{2015} & \multicolumn{3}{|c|}{2016} \\
\hline & & & & \multirow{2}{*}{\begin{tabular}{|c|} 
Weight of \\
mature \\
berries $(\mathrm{g})$ \\
2015 \\
\end{tabular}} & \multirow{2}{*}{$\begin{array}{l}\text { Weight } \\
\text { of must } \\
\text { obtained } \\
(\mathrm{g})\end{array}$} & \multirow{2}{*}{$\begin{array}{c}\text { Percentage } \\
\text { of weight } \\
\text { transforma- } \\
\text { tion }\end{array}$} & \multirow{2}{*}{\begin{tabular}{|c|} 
Weight \\
of mature \\
berries $(\mathrm{g})$ \\
2016 \\
\end{tabular}} & \multirow{2}{*}{$\begin{array}{l}\text { Weight } \\
\text { of must } \\
\text { obtained } \\
\quad(\mathrm{g})\end{array}$} & \multirow{2}{*}{$\begin{array}{c}\text { Percentage } \\
\text { of weight } \\
\text { transforma- } \\
\text { tion }\end{array}$} \\
\hline & & From & To & & & & & & \\
\hline \multirow{2}{*}{1} & \multirow{2}{*}{$\begin{array}{l}\text { Iregua } \\
\text { river }\end{array}$} & $42^{\circ} 16^{\prime} 48^{\prime \prime} \mathrm{N}$ & $\sqrt{42^{\circ} 16^{\prime} 40^{\prime \prime} \mathrm{N}}$ & \multirow[b]{2}{*}{1272} & \multirow[b]{2}{*}{195} & \multirow[b]{2}{*}{15.3} & \multirow[b]{2}{*}{1489} & \multirow[b]{2}{*}{240} & \multirow[b]{2}{*}{16.1} \\
\hline & & $\begin{array}{c}2^{\circ} 35^{\prime} 10^{\prime \prime} \mathrm{W} \\
702 \mathrm{~m}\end{array}$ & $\begin{array}{c}2^{\circ} 35^{\prime} 17^{\prime \prime} \mathrm{W} \\
704 \mathrm{~m}\end{array}$ & & & & & & \\
\hline \multirow{2}{*}{2} & \multirow{2}{*}{$\begin{array}{l}\text { Agualinos } \\
\text { creek }\end{array}$} & $42^{\circ} 32^{\prime} 28^{\prime \prime} \mathrm{N}$ & $42^{\circ} 32^{\prime} 26^{\prime \prime} \mathrm{N}$ & \multirow[b]{2}{*}{1497} & \multirow[b]{2}{*}{237} & \multirow[b]{2}{*}{15.8} & \multirow[b]{2}{*}{1676} & \multirow[b]{2}{*}{248} & \multirow[b]{2}{*}{14.6} \\
\hline & & $\begin{array}{c}2^{\circ} 54^{\prime} 43^{\prime \prime} \mathrm{W} \\
506 \mathrm{~m}\end{array}$ & $\begin{array}{c}2^{\circ} 54^{\prime} 53^{\prime \prime} \mathrm{W} \\
506 \mathrm{~m}\end{array}$ & & & & & & \\
\hline \multirow[b]{2}{*}{3} & \multirow{2}{*}{$\begin{array}{l}\text { Ebro } \\
\text { river }\end{array}$} & $42^{\circ} 45^{\prime} 36^{\prime \prime} \mathrm{N}$ & $42^{\circ} 45^{\prime} 57^{\prime \prime} \mathrm{N}$ & \multirow[b]{2}{*}{1615} & \multirow[b]{2}{*}{263} & \multirow[b]{2}{*}{16.3} & \multirow[b]{2}{*}{1934} & \multirow[b]{2}{*}{298} & \\
\hline & & $\begin{array}{c}3^{\circ} 7^{\prime} 17^{\prime \prime} \mathrm{W} \\
509 \mathrm{~m}\end{array}$ & $\begin{array}{c}3^{\circ} 5^{\prime} 38^{\prime \prime} \mathrm{W} \\
486 \mathrm{~m}\end{array}$ & & & & & & 15.4 \\
\hline & & $43^{\circ} 02^{\prime} 27^{\prime \prime} \mathrm{N}$ & $43^{\circ} 2^{\prime} 30^{\prime \prime} \mathrm{N}$ & & & & & & \\
\hline 4 & Amurrio & $\begin{array}{c}2^{\circ} 59^{\prime} 25^{\prime \prime} \mathrm{W} \\
248 \mathrm{~m}\end{array}$ & $\begin{array}{c}2^{\circ} 59^{\prime} 24^{\prime \prime} \mathrm{W} \\
243 \mathrm{~m}\end{array}$ & 1462 & 241 & 16.5 & 1731 & 280 & 16.2 \\
\hline & & $43^{\circ} 19^{\prime} 16^{\prime \prime} \mathrm{N}$ & & & & & & & \\
\hline 5 & $\begin{array}{l}\text { Saturraran } \\
\text { beach }\end{array}$ & $\begin{array}{c}2^{\circ} 24^{\prime} 37^{\prime \prime} \mathrm{W} \\
8 \mathrm{~m}\end{array}$ & & 1985 & 331 & 16.7 & 2089 & 322 & 15.4 \\
\hline & & $43^{\circ} 20^{\prime} 05^{\prime \prime} \mathrm{N}$ & $\sqrt{43^{\circ} 18^{\prime} 02^{\prime \prime} N}$ & & & & & & \\
\hline 6 & $\begin{array}{l}\text { Diudsud } \\
\text { river }\end{array}$ & $\begin{array}{c}1^{\circ} 45^{\prime} 12^{\prime \prime} \mathrm{W} \\
11 \mathrm{~m}\end{array}$ & $\begin{array}{c}1^{\circ} 43^{\prime} 58^{\prime \prime} \mathrm{W} \\
12 \mathrm{~m}\end{array}$ & 1967 & 302 & 15.3 & 2103 & 336 & 16.0 \\
\hline & & $43^{\circ} 23^{\prime} 21^{\prime \prime} \mathrm{N}$ & $43^{\circ} 23^{\prime} 19^{\prime \prime} \mathrm{N}$ & & & & & & \\
\hline 7 & Sokoa & $\begin{array}{c}1^{\circ} 41^{\prime} 58^{\prime \prime} \mathrm{W} \\
41 \mathrm{~m}\end{array}$ & $\begin{array}{c}1^{\circ} 41^{\prime} 54^{\prime \prime} \mathrm{W} \\
35 \mathrm{~m}\end{array}$ & 1916 & 313 & 16.3 & 2164 & 323 & 14.9 \\
\hline & & $43^{\circ} 23^{\prime} 08^{\prime \prime} \mathrm{N}$ & $43^{\circ} 23^{\prime} 01^{\prime \prime} \mathrm{N}$ & & & & & & \\
\hline 8 & $\begin{array}{l}\text { Chemin } \\
\text { d'Etzan }\end{array}$ & $\begin{array}{c}1^{\circ} 42^{\prime} 42^{\prime \prime} \mathrm{W} \\
19 \mathrm{~m}\end{array}$ & $\begin{array}{c}1^{\circ} 42^{\prime} 37^{\prime \prime} \mathrm{W} \\
34 \mathrm{~m}\end{array}$ & 1817 & 289 & 15.9 & 2027 & 306 & 15.1 \\
\hline & Acotz- & $43^{\circ} 24^{\prime} 58^{\prime \prime} \mathrm{N}$ & $43^{\circ} 24^{\prime} 55^{\prime \prime} N$ & & & & & & \\
\hline 9 & Guéthary & $\begin{array}{c}1^{\circ} 36^{\prime} 44^{\prime \prime} \mathrm{W} \\
25 \mathrm{~m}\end{array}$ & $\begin{array}{c}1^{\circ} 36^{\prime} 44^{\prime \prime} \mathrm{W} \\
27 \mathrm{~m}\end{array}$ & 1857 & 284 & 15.3 & 2071 & 325 & 15.7 \\
\hline
\end{tabular}

Table 1.- Coordinates of the different sampling places and the percentages of must extracted from the total weight of mature berries.

Tabla 1.- Coordenadas de los diferentes lugares de muestreo y los porcentajes de mosto extraídos del peso total de las bayas maduras. 
These mixtures were fermented at $20^{\circ} \mathrm{C}$ with native yeasts and removing twice a day during 15-18 days, when the alcoholic fermentation stopped. In any case there was not Potassium metabisulphite addition.

The analytical methods used on wine samples were obtained following the procedures described by OIV (2015), in particular the parameters and methods used were: The Brix degrees: refractometric method; Ethanol concentration: MA-F-AS2-02; pH- pHmeter, Total acidity: Valoration; Tartaric acid: Colorimetric; L-malic acid: Enzymatic; Total polyphenol index (optical density $280 \mathrm{~nm}$ ); Anthocyanins: UV-VIS spectrometry; Color intensity: UV-VIS spectrometry; Total poliphenol index: UV-VIS spectrometry. The datum of color intensity is the sum of values of absorbance obtained at 420, 520 and $620 \mathrm{~nm}$. Analytical data were obtained always before malo-lactic fermentation starting.

\section{Results and discussion}

Table2 shows the Brix degree of the musts and Table3 shows the values of the obtained parameters of the different microvinifications. The central column stands for year 2015 and the column on the right for year 2016.

The amount of must obtained is very low in each microvinification: it is situated between 15.3 and $16.7 \%$ in weight. This is due to the small size of the berries, which contain a little amount of pulp, because the seeds (1 or 2) are quite bulky and berries have less than $1 \mathrm{~cm}$ of diameter.

The climatic conditions of each harvest mark the maturation and the wines obtained. In the case of the 2015 and 2016 harvests, a certain parallelism between commercial and wild wines is manifested. For example, in DOC (registered designation of origin) Rioja in Spain, the average alcoholic strength of the 2015 harvest was $14.15^{\circ}$ and in 2016 it was $13.44^{\circ}$, in line with the results obtained in the experiment.

The vegetative cycle is clearly longer in the case of wild vines. For example, in the 2015, the harvest had been concluded in Rioja Qualified Designation of Origin in

\begin{tabular}{|c|c|c|c|c|c|c|c|c|c|}
\hline & $\begin{array}{c}1 \\
\text { Iregua }\end{array}$ & $\begin{array}{c}2 \\
\text { Agualinos }\end{array}$ & $\begin{array}{c}3 \\
\text { Ebro }\end{array}$ & $\begin{array}{c}4 \\
\text { Amurrio }\end{array}$ & $\begin{array}{c}5 \\
\text { Saturraran }\end{array}$ & $\begin{array}{c}6 \\
\text { Bidasoa }\end{array}$ & $\begin{array}{c}7 \\
\text { Sokoa }\end{array}$ & $\begin{array}{c}8 \\
\text { Chemin } \\
\text { d'Etzan }\end{array}$ & $\begin{array}{c}9 \\
\text { Acotz- } \\
\text { Guéthary }\end{array}$ \\
\hline 2015 & 13.8 & 14.1 & 13.1 & 14.7 & 15.4 & 15.4 & 15.1 & 16.5 & 15.6 \\
\hline 2016 & 13.0 & 13.6 & 12.6 & 14.2 & 14.8 & 14.6 & 14.6 & 15.3 & 15.0 \\
\hline
\end{tabular}

Table 2.- Sugar concentration (Brix degrees) of the musts in years 2015 and 2016.

Tabla 2.- Concentración de azúcar (grados Brix) de los mostos en los años 2015 y 2016. 


\begin{tabular}{|c|c|c|c|c|c|c|c|c|c|c|c|c|c|c|c|c|c|c|}
\hline & \multicolumn{2}{|c|}{$\begin{array}{c}1 \\
\text { Iregua }\end{array}$} & \multicolumn{2}{|c|}{$\begin{array}{c}2 \\
\text { Agualinos }\end{array}$} & \multicolumn{2}{|c|}{$\begin{array}{c}3 \\
\text { Ebro }\end{array}$} & \multicolumn{2}{|c|}{$\begin{array}{c}4 \\
\text { Amurrio }\end{array}$} & \multicolumn{2}{|c|}{$\begin{array}{c}5 \\
\text { Saturraran }\end{array}$} & \multicolumn{2}{|c|}{$\begin{array}{c}6 \\
\text { Bidasoa }\end{array}$} & \multicolumn{2}{|c|}{$\begin{array}{c}7 \\
\text { Sokoa }\end{array}$} & \multicolumn{2}{|c|}{$\begin{array}{c}8 \\
\text { Chemin } \\
\text { d'Etzan }\end{array}$} & \multicolumn{2}{|c|}{$\begin{array}{c}9 \\
\text { Acotz- } \\
\text { Guéthary }\end{array}$} \\
\hline & 2015 & 2016 & 2015 & 2016 & 2015 & 2016 & 2015 & 2016 & 2015 & 2016 & 2015 & 2016 & 2015 & 2016 & 20152 & 2016 & 2015 & 2016 \\
\hline $\begin{array}{c}\text { Percentage } \\
\text { of ethanol } \\
(\% \mathrm{v} / \mathrm{v})\end{array}$ & 7.2 & 6.7 & 7.4 & 7.1 & 6.8 & 6.5 & 7.8 & 7.5 & 8.3 & 7.9 & 8.3 & 7.7 & 8.1 & 7.7 & 9.0 & 8.2 & 8.4 & 8.0 \\
\hline $\mathrm{pH}$ & 3.1 & 2.8 & 3.3 & 3.0 & 3.0 & 2.7 & 3.2 & 3.0 & 3.5 & 3.1 & 3.2 & 3.0 & 3.4 & 2.9 & 3.3 & 2.8 & 3.1 & 2.7 \\
\hline $\begin{array}{l}\text { Total acidity } \\
\text { (g of tarta- } \\
\text { ric acid) }\end{array}$ & 16.4 & 18.2 & 15.2 & 16.4 & 15.1 & 16.5 & 17.2 & 17.7 & 16.1 & 16.8 & 15.8 & 16.2 & 14.9 & 15.3 & 15.41 & 16.1 & 14.9 & 16.4 \\
\hline $\begin{array}{l}\text { Tartaric } \\
\text { acid } \\
(\mathrm{g} / \mathrm{l})\end{array}$ & 6.5 & 7.2 & 6.2 & 7.0 & 5.9 & 7.0 & 6.8 & 7.3 & 6.1 & 6.7 & 5.9 & 6.4 & 6.1 & 6.6 & 5.6 & 6.8 & 5.3 & 7.1 \\
\hline $\begin{array}{l}\text { L malic } \\
\text { acid } \\
(\mathrm{g} / \mathrm{l})\end{array}$ & 2.6 & 2.3 & 2.8 & 2.5 & 2.4 & 2.1 & 2.1 & 2.4 & 2.5 & 2.8 & 2.1 & 2.3 & 2.9 & 2.7 & 2.9 & 2.7 & 2.5 & 2.3 \\
\hline $\begin{array}{c}\text { Total } \\
\text { polyphenol } \\
\text { index (o.d. } \\
280 \mathrm{~nm} \text { ) }\end{array}$ & 107 & 99 & 101 & 95 & 99 & 92 & 102 & 98 & 102 & 95 & 96 & 92 & 87.1 & 79.4 & 75.37 & 70.6 & 69.4 & 65.8 \\
\hline $\begin{array}{l}\text { Antho- } \\
\text { cyanins } \\
\text { (mg/l) }\end{array}$ & 518 & 502 & 511 & 483 & 510 & 489 & 507 & 479 & 513 & 492 & 487 & 463 & 531 & 502 & 511 & 497 & 498 & 470 \\
\hline $\begin{array}{c}\text { Color } \\
\text { intensity }\end{array}$ & 23 & 21 & 20 & 18 & 22 & 18 & 19 & 17 & 20 & 19 & 17 & 15 & 23 & 22 & 20 & 18 & 17 & 15 \\
\hline
\end{tabular}

Table 3.- Values of the analyzed parameters for each microvinification in years 2015 and 2016.

Tabla 3.- Valores de los parámetros analizados para cada microvinificación en los años 2015 y 2016.

October 12, meanwhile the harvest of wild grapes was done, at least, two weeks later. This character could be of great interest in many of the varieties grown in the warmest areas of the Mediterranean region. In these areas the end of ripening occurs in climatic conditions of excess heat throughout the day which produces grapes with a high concentration of sugars, very low acidity, little varietal character and a slightly stable colour.

Analytical data show important differences with those obtained with different cultivars. It is due, logically, to the fact that wild grapevines are free of a large human selection, as in the case of cultivars, as it was indicated in other wild wines from populations close to the sampling places of the present paper (Meléndez et al. 2016). On the other hand, it is necessary to remark the presence of a great diversity of indigenous yeasts in wild populations (Puig Pujol et al., 2016), different to selected 
commercial ones used at present by oenologists in cellars, giving different characters to the fermentation.

The acid content of the wines obtained is interesting. The proportion present in the wine of malic and tartaric acids is striking. For example $16.5 \mathrm{~g}$ tartaric $/ 2.5 \mathrm{~g}$ of malic acid in the wines of the experiment against a content of $12.7 \mathrm{~g}$. of tartaric and 7.76 g. malic acid. Due to small size of wild berries and the low production of fruits, they are very interesting because of the large surface area ratio they would have, compared to the cultivated varieties. This factis in line with the amount of polyphenols found in the wines. It would also be interesting to be able to evaluate the aromatic phase of these wines. In both harvests the total acidity values are high due to the heavy content of tartaric acid, situated between 5.3 and $7.2 \mathrm{~g} / \mathrm{l}$ with $\mathrm{pH}$ values situated between 2.7 and 3.5, being 3.4 the optimal value for the commercial red wine in Spain (García-Barceló, 1976). Ethanol concentration issituated between 6.5 and 9.0. The map in figure 2 shows that the values grow the further north the population is, in coincidence with the increase of the mean temperature of the areas closer to the coast and lower altitude. In any case, the values are lower than in Extremadura (Ambroz valley) and Andalusia (Rivera de Huelva river) regions located further South of Spain, where some microvinifications contained up to $14.85 \%$ of alcohol (Ayala et al., 2011; ArroyoGarcía et al., 2016). Likewise, the total polyphenol index in all samples is high in the two years of follow-up, obtaining higher values in 2015, between 97 and 107 at 280 $\mathrm{nm}$. The color intensity of wines presents high values, between 15 and 23 . This fact is closely related to the high content of total polyphenols and anthocyanins, these last ones varies between 470 and $531 \mathrm{mg} / \mathrm{l}$. Regarding the total polyphenol index, which is included in theinterval (65.8-107) all wines are considered to have very good values for young red wines. As it is known, the quality characteristics that define a red wine are largely related to the values indicates in the present paragraph.

From the oenological point of view, it should be noted that in the two years of microvinifications the components responsible for the colour and astringency in red wines present very adequate values, with a high total polyphenol concentration, which indicates that even these wines could have capacity for aging, as long as this colour is maintained over time. The polyphenolic matter is transcendent to understand the aging of the wine as it influences the colour and taste of the wines, and, on the other hand, some aromatic influences.

In all the samples the colour intensity was lower than the obtained in a close population belonging to Santa Cruz de Campezo (Álava province) in 2014, which was over 25 , due to a higher concentration of anthocyanins and the total polyphenols (Meléndez et al., 2016).

Phenolic compounds are one of the largest phytochemical groups, of considerable morphological and physiological importance in plants. These compounds play an 
important role in growth and reproduction, providing protection against pathogens and predators (Bravo, 1998). They also contribute to the colour and sensory characteristics of fruits and vegetables (Alasalvar et al., 2001).

The polyphenolic composition of the wines depends on the grape variety and other factors that affect the development of the grape, such as soil, geographical location and climatic conditions (Neuza et al., 2007). In the pulp of the grapes are the nonflavonoid compounds while the flavonoid compounds are located in the skin, seeds and cluster (Blouin et al., 2012). Anthocyanins are the main pigment in grape berries (Revilla et al., 2019; Ferreira et al., 2019) and characterize grapes and red wines, mean while they are absent in white grapes and wines. They constitute both qualitatively and quantitatively an important part of the flavonoids of the lows of red grapes and, consequently, of the resulting wines (Valls et al., 2000). The anthocyanins are the red pigments of the skins of the red grapes and their accumulation develops parallel to the accumulation of sugars. In coloured pulp varieties, anthocyanins are present in the pulp cells 5-15 times less than in skin cells, although weather conditions greatly influence this accumulation. The percentages of anthocyanins vary with the grape variety and with the degree of ripening. The anthocyanins have an intense red-violet color in an acid medium, like in the case of these wines. Their concentration varies between 470 and $518 \mathrm{mg} / \mathrm{l}$ in this wild microvinifications.

Flavanols are present in seeds, although they also exist in smaller amounts in the wall of the skins, in a monomer state and in more or less polymerized forms. The most abundant monomers are catechins, epicatechin, gallocatechin and epigallocatechin. The polymerization of these monomers produces tannins because of their property of combining with the protids and causing their precipitation provoking astringency. The tannins that the grape naturally contains, and in consequence the wines, are the condensates (Aleixandre et al., 2003).

However, phenolic compounds have healthy properties and are responsible for the organoleptic qualities of wine such as colour, structure or its potential to be aged. The composition and the phenolic concentration are influenced by several factors such as the grape variety and the ripeness of the grape, the maceration of the skins, the different systems of vinification (Hernández-Saseta et al., 2015).

In oenology it is important to know the content of polyphenols, because in a young wine, the colour depends on its composition in free anthocyanins and its copigments and when the wine ages, the free anthocyanins disappear due to their oxidation, or their combination with the flavanols or mediated by the ethanal (Lizama et al., 2015). Low pH values determine wines with greater freshness, liveliness, being a decisive parameter in the balance of the wines, so that a very fresh acidity can make pleasant light wines, of low alcoholic concentration, that would be bland and watery with a level of acidity very low. The viticulture in the Mediterranean region, including the 
Iberian Peninsula, has been consolidated on a global scale through the quality of its management and the quality of the harvest, which has been developed by agronomic methods based on the ecophysiologic and genetic knowledge of the varieties and root-stocks of its vineyards (Savé et al., 2018). Finally it is necessary to foreground the high values of colour intensity and total acidity of the microvinifications of wild grapevine sampled. Two important characteristics to be transmitted to red cultivars, due to diminution of this parameters by cause of the climate change. So, in some Southern Spanish wine producing areas the Syrah variety, due to its high colouring ability, has been recently introduced. That possibility was also taken into account in Albania, where there are interesting phenotypes, female and hermaphrodites, to be collected, stored, and used in programs for the creation of new cultivars and the improvement of the existing varieties which are used in the production of red wine (Ferraj et al., 2014).

Biodiversity loss is a worldwide problem, and the vine is probably one of the most affected species. The number of cultivated varieties of vine has decreased in recent years, and the local varieties of each region has been displaced by other varieties that have expanded internationally due to globalization of markets (Marsal et al., 2017).

\section{Conclusions}

According to the analytical results of microvinifications, mainly good acidity and highcolor intensity, it is necessary to remark that both interesting characteristics are also conserved in experimental red wines obtained from grafted cultivated wild grapevines in the germplasm bank belonging to IFAPA Rancho de la Merced (Jerez de la Frontera) from 2002. It is situated in Andalusia under a warmer climatology. Due to cited facts, the Eurasian wild grapevine could be a very interesting phytogenetic resource in order to getmore suitable cultivars. It is necessary to start a program for breeding of traditional cultivars and to make a selection of germplasm in order to reduce the negative impacts derived from the problem of climatic change. This circumstance is forcing the elevation or increasing the latitude for the plantation of new vineyards, like in the case of United Kingdom and Poland, for example.

Another analytic data are not similar to those obtained from cultivars. So, it is necessary to take into account that these grapevines are not selected by manto produce wines. On the other hand, they are not subject to cultivation. They lack pruning, plowing and manual bunch reduction tasks, cleaning of the surrounding vegetation and the application of chemical fertilizers and phytosanitary treatments. They produce only berries for their sexual reproduction by seeds and mainly to be spread mainly by different bird species. 
Furthermore, in warm producing wine areas, some vineyards of female grapevine could be planted in order to use this acid must instead of tartaric addition, increasing the red coloration of them at the same time.

\section{Acknowledgements}

The present paper is dedicated to the great researcher of the vineyard and the wine Professor Alain Huetz of Lemps from the Michel de Montaigne University of Bordeaux and to his wife Nicole.

\section{Bibliography}

Alasalvar, C., Grigor, J.M., Zhang, D.,Quantick, P.C., Shahidi, F., 2001. Comparison of volatiles, phenolics, sugars, antioxidant vitamins, and sensory quality of different colored carrot varieties. J. Agric. Food Chem. 49, 1410-1416.

Aleixandre, J.L., Álvarez, M.I., 2003. Tecnología enológica. Ed. Síntesis, Madrid.

Anderson, K., Aryal, N.R., 2017. Which winegrape varieties are grown where? A global empirical picture. University of Adelaide Press.

Arnold, C., 2002. Écologie de la vigne sauvage en Europe (Vitis vinifera ssp. sylvestris). Geobotánica helvetica 76.

Arroyo-García, R., Cantos, M., Lara, M., López, M.A., Gallardo A., Ocete, C.A., Pérez, A., Bánáti, H., García, J.L., Ocete, R., 2016. Characterization of the largest relic Eurasian wild grapevine reservoir in Southern Iberian Peninsula. Span. J. Agric. Res. 14(3), e0708 https://doi.org/10.5424/sjar/2016143-8929

Arroyo-García, R., Ruiz-Garcia, L., Bolling, L., Ocete, R., López, M.A, Arnold, C., Ergul, A., Soÿlemezoglu, G., Uzun, H.I., Cabello, F., Ibáñez, J., Aradhya, M.K., Atanassov, A., Atanassov, I., Balint, S., Cenis, J.L., Costantini, L., Gorislavets, S., Grando, M.S., Klein, B.Y., McGovern, P.E., Merdinoglu, D., Pejic, I., Pelsy, F., Primikirios, N., Risovannaya, V., Roubelakis-Angelakis, K.A., Snoussi, H., Sotiri, P., Tamhankar, S., This, P., Troshin, L., Malpica, J.M., Lefort, F., Martinez-Zapater, J.M., 2006. Multiple origins of cultivated grapevine (Vitis vinifera L. ssp. sativa) based on chloroplast DNA polymorphisms. Mol EcolResour 15, 37073717.

Ayala, M.C., Ocete, R., García-Moreno, M.P., Armendáriz, I., 2011. Vinificación con poblaciones de vid silvestre del Valle de Mena (Burgos) y del Valle del Ambroz (Cáceres). En: XXXIII Jornadas de Viticultura y Enología de Tierra de Barros, 143-155.

Anzani, R., Failla, O., Scienza, A., Micheli L.de, 1993. Individuazioni e conservacione del germoplasma de vite selvática (Vitis vinifera sylvestris) in Italia. Vignevino 6, 51-60.

Ben-Nun, L., 2018. Medicinal effects of grapes. Ed. B.N. Publication House, Israel. 
Blouin, J., Gimberteau, G, 2004. Maduración y madurez de la uva. Mundi Prensa, Madrid. Bravo, L., 1998. Polyphenols: chemistry, dietary sourdes, metabolism, and nutritional significance. Nutr. Rev. 56, 317-333.

Chilashvili, L., 2004. The vine, Wine and Georgians. Petite publisher, Tbilisi (Georgian).

De Andrés, M.T., Benito, A., Pérez-Rivera, G., Ocete R., Lopez, M.A., Gaforio, L., Muñoz, G., Cabello, F., Martinez-Zapater, J.M., Arroyo-Garcia, R., 2012. Genetic diversity of wild grapevine populations in Spain and their genetic relationships with cultivated grapevines. Mol. Ecol. 21, 800-816. https://doi.org/10.1111/j.1365-294X.2011.05395.x

Ferraj, B., Shumeli, A., Susaj, L., 2014. Ampelographic evaluation of wild grapevine characters Vitis vinifera ssp. sylvestris in Vlora's river valley. Albanian J. Agric. Sci. 13(2), 131-135.

Ferreira, V., Matus, J.T., Pinto-Carnide, O., Carrasco, D., Arroyo-García, R., Castro, I., 2019. Genetic analysis of a white-to-red berryskincolor reversion and its transcriptomicand metabolic consequences in grapevine (Vitis vinifera cv. "Moscatel Galego"). BMC Genom. 20, 952 https://doi.org/10.1186/s12864-019-6237-5

García-Barceló, J., 1976. Métodos de análisis de vinos y derivados. Ed. Sepsa, Sevilla.

García-Novo, F., 2007. La diversidad biológica. Real Academia de Ciencias Exactas, Físicas y Naturales, Madrid.

Gallardo, A., Ocete, R., López, M.A., Lara, M., Rivera, D., 2009. Assessment of the pollen polymorphism in populations of wild grapevine. Vitis 48(2), 59-62.

Hernández-Saseta, I., González Lázaro, L., Guadalupe, Z., Ayestarán, B., Bueno-Herrera, M., González Huerta, C., López de la Cuesta P., Pérez-Magariño, S., 2015. Elaboración de los vinos espumosos de calidad a partir de variedades tintas. Efecto de diferentes técnicas vitivinícolas en la composición polifenólica. Enología: Grupos de investigación enológica $11,308-311$.

Lizama, V., Álvarez, I., Peidró, M.J., Alexaindre, J.L., Aleixandre-Tudó, J.L., 2015. Efecto del tipo de depósito sobre la evolución de los parámetros polifenólicos en vinos tintos. Enología: Grupos de Investigación Enológica 16, 324-327.

Lovicu, G., 2008. La Sardena della vite è selvatica, antica, biodiversa. Vini e Vitigni. Darwin Quaderni, 3.

Mariani, L., Cola, G., Maghradze, D., Failla, O., Zavatti, F., 2018. Influence of climate cycles on grapevine domestication and ancient migrations in Eurasia. Sci. Total Environ. 635, $1240-1254$.

Martínez de Toda, F., Ocete, R., Prado, E., Rodríguez, Á., Valle, J.M., 2017. La vid silvestre en La Rioja (España). Situación actual y difusión mediante infraestructuras de datos espaciales. Zubia 29, 95-120.

Marsal, G., Bota, J., Martorell, A., Canals, J.M., Zamora, F., Fort, F., 2017. Local cultivars of Vitis vinifera L. in Spanish islands: Balearic Archipelago. Sci. Hortic. 226, 122-132. 
Martínez de Toda F., 1991. Biología de la vid, fundamentos biológicos de la viticultura. Mundi-Prensa, Madrid.

McGovern, P.E., 2003. Ancient Wine: The Search for the origins of Viniculture. Princeton University.

McGovern, P.E., 2004. Wine and Eurasian grape: Archaeological and chemical perspectives on their origins. In: Actas do III simpósio da Associaçao International de História e Civilizaçao da Vinha e do Vinho, 291-307. Funchal, Madeira.

Meléndez, E., Puras, P., García, J.L., Cantos, M., Gómez-Rodríguez, J.A., Íñiguez, M., Rodríguez, Á., Valle, J.M., Arnold, C., Ocete, C.A., Ocete, R., 2016. Evolution of wild and feral vines from the Ega River gallery forest (Basque Country and Navarra, Spain) from 1995 to 2015. J. Int.Sci. VigneVin, 50(2), 65-75.

Neuza, P., Perestrelo, R., Marques, J.C., Camara, J.S., 2007. Relationship between antioxidant capacity and total phenolic content of red, rose and white wines. Food Chem. 105, 204-214.

Ocete, R., López M.A., Gallardo, A., Arnold, C., Pérez, M.A., Rubio, I. 2004. Euskal Herriko eta inguruetakobasamahatsandoa: ekologia, kokapena eta arriskuak. Servicio Central de Publicaciones del Gobierno Vasco, Vitoria-Gasteiz.

Ocete, R., Cantos, M., López, M.A., Gallardo, A., Pérez, M.A., Troncoso, A., Lara M., Failla, O., Ferragut, F.J., Liñán, J., 2007. Caracterización y conservación del recurso fitogenético vid silvestre en Andalucía. Consejería de Medio Ambiente, Junta de Andalucía, Sevilla.

Ocete, R., Fevereiro, P., Failla, O., 2015. Proposal for the wild grapevine (Vitis vinifera L. subsp. sylvestris (Gmelin) Hegi) conservation in the European countries. Vitis 54 (Special Issue), 281-282.

O.I.V. (Organisation Internationale de la Vigne et du Vin), 2009. Descriptor list for grape varieties and Vitis species. A. Dendon, Paris.

O.I.V. (Organisation Internationale de la Vigne et du Vin), 2015. Recueil des méthodes internationales d'analyse des vins et des moûts.O.I.V., Paris (France).

Puig-Pujol, A., Ferrando, N., Capdevila, F., Ocete, R., Revilla, E., 2016. Yeast biodiversity from Vitis vinifera L., subsp. sylvestris (Gmelin) Hegi to face up the oenological consequences of climate change. BIO Web of Conferences (7).

République Française, 1982. Arrêté du 20 janvier 1982 fixant la liste des espèces végétales protégées sur l'ensemble du territoire (Version consolidée au 10 octobre 2018). Available from:

https://www.legifrance.gouv.fr/affichTexte.do?cidTexte=LEGITEXT000028511423\&dateTexte $=20181010$ (access in November 2019).

Revilla, E., Carrasco, D., Benito, A., Arroyo-García, R., 2019. Anthocyanin fingerprint of different genotypes of wild grapes (Vitis vinifera subsp. sy/vestris (Gmelin) Hegi). J. Berry Res. 9(1), 63-82. https:/doi.org/10.3233/JBR-180304. 
Rodríguez-Miranda, Á., Hidalgo, J., Arrimadas, J., Ocete, C.A., Duhart, F., Ocete, R., Iriarte-Chiapusso, M.J., Valle, J.M., 2016. El impacto antrópico sobre la vid silvestre en el territorio de Lapurdi (suroeste de Francia). Munibe Cienc. nat. 64, 79-98.

Savé, R., 2018. Habrá que replantearse en el futuro el concepto de producción. Enoviticultura 54, 43-47.

Susaj, L., Susaj, E., Jashari, F., 2014. Mature Leaf Features of Wild Grapevine: Populations grown in Three Different River Valleys of North Albania. Albanian J. Agric. Sci. (Special edition).

Terral, J.F., Tabard, E., Bouby, L., Ivorra, S., Pastor, T., Figueiral, I., Picq, S., Chevance, J.P., Jung, C., Fabre, L., Tardy, C., Compan, M., Bacilieri, R., Lacombe, T., This P., 2010. Evolution and history of grapevine (Vitis vinifera) under domestication: new morphometric perspectives to understand seed domestication syndrome and reveal origins of ancient European cultivars. Ann Bot. 105(3), 443-455.

Terpó, A., 1969. A Vitis syilvestris Gmel. Magyar Középhegységi termöhely i Viszonyainak vizsgálata. Bot. Közlem 56(1), 27-35.

Valls J., Lampreave M., Nadal M., Arola L., 2000. Importancia de los compuestos fenólicos en la calidad de los vinos tintos de crianza. Alim. Equipos y Tecnología 2, 119-124.

Zito, P., Scrima, A., Sajeva, M., Carimi, F., Dötterl S., 2016. Dimorphism in inflorescence scent of dioecious wild grapevine. Biochem. Syst. Ecol. 66, 58-62.

Zdunic, G., Maul, E., Hancevic, K., Leko, M., Butorac, L., Mucalo, A., Radic, T., Simon S., Budic-Leto, I., Mihaljevic, M.Z., Maletic, E., 2017. Genetic Diversity of Wild Grapevine (Vitis vinifera subsp. sylvestris Gmel Hegi) in the Eastern Adriatic Region. Am. J. Enol. Vitic. https://doi.org/10.5344/ajev.2016.16072.

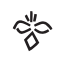

Fecha de recepción/ Date of reception: 25/03/2020

Fecha de aceptación / Date of acceptance: 19/05/2020 Editor Asociado / Associate editor: Cristina Herrero-Jáuregui 